\title{
La crítica de Nicholas Agar a los programas de mejora radical en humanos
}

\section{Nicholas Agar's critics toward human enhancement programs}

\author{
MIGUEL MORENO MUÑOZ*
}

\begin{abstract}
Resumen: El propósito de este trabajo es mostrar el interés y la utilidad del análisis de las tecnologías de mejora funcional y cognitiva en humanos que desarrolla Nicholas Agar en sus obras Liberal Eugenics (2004) y Humanity's End (2010). Además de constatar la evolución en diversos aspectos que parecen haber condicionado la percepción pública y el debate social en línea con sus intuiciones en estas obras, mi aproximación destaca varios puntos fuertes que refuerzan la calidad del enfoque prospectivo de Agar en relación con las biotecnologías reproductivas, frente a las propuestas surgidas de autores a menudo caracterizados como bioconservadores. Los apartados finales aportan elementos adicionales para considerar el análisis de Agar preferible al que llevan a cabo otro grupo de autores que comparten con Agar cierto optimismo pragmático, pero que articulan reflexiones muy dispares y menos cautelosas sobre los riesgos de la inteligencia artificial, la robótica y la biónica.

Palabras clave: mejora cognitiva, eugenesia liberal, inteligencia artificial, Nicholas Agar.
\end{abstract}

\begin{abstract}
The purpose of this paper is to show the interest and usefulness of Nicholas Agar's analysis of technologies for functional and cognitive enhancement, developed in Liberal Eugenics (2004) and Humanity's End (2010). In addition to note the evolution in some aspects which seem to have influenced the public perception and social debate according to Agar's intuitions in these works, my approach highlights several strengths associated with his prospective regarding reproductive biotechnologies, in contrast with some proposals from authors often characterized as bioconservatives. The final sections provide additional elements to consider Agar's analysis preferable to some authors in some way very close to Agar's pragmatic optimism, but less cautious about the risks of artificial intelligence, robotics and bionics.
\end{abstract}

Keywords: cognitive enhancement, liberal eugenics, artificial intelligence, Nicholas Agar.

Fecha de recepción: 11/06/2016. Fecha de aceptación: 25/07/2016.

* Universidad de Granada. Profesor Contratado Doctor. Coordinador del Grado en Filosofía (mm3@ugr.es) Líneas recientes de investigación: Aspectos éticos, sociales y legales de las biotecnologías, en particular los relacionados con las tecnologías de mejora humana. Últimas publicaciones: Moreno Muñoz, M. (2016): "Riesgos asociados al desarrollo de robots autónomos dotados de inteligencia artificial avanzada en contexto civil y militar". Ensayos de Filosofía, n 3, 2016/1: 1-12; Moreno Muñoz, M. (2016): “Opciones de mejora cognitiva no convencional como respuesta al desempleo estructural en el contexto tecnológico de la cuarta revolución industrial”. Gazeta de Antropología, $\mathrm{n}^{\circ} 32 / 2$. http://www.gazeta-antropologia.es/?p=4903 


\section{Introducción}

Las aportaciones de Nicholas Agar al debate sobre el empleo de tecnologías de mejora en seres humanos se producen en un contexto muy marcado por el carácter especulativo de las primeras propuestas favorables a la introducción de mejoras radicales -funcionales y cognitivas- en humanos, centradas inicialmente en posibles transformaciones biotecnológicas (clonación, ingeniería genética, terapia génica y selección de embriones, entre otras).

En esta línea iban las tesis representativas de la posición inicial de Nicholas Agar en Liberal Eugenics (2004) ${ }^{1}$, donde defiende el recurso a la clonación, a la terapia genética y a otras biotecnologías que podrían permitir a los progenitores mejorar algunas características de su descendencia. Se ubicaba así en un planteamiento de libre mercado, con un concepto de eugenesia muy ligado a la posibilidad de libre elección individual. Su enfoque inicial se sustentaba en un claro énfasis en las libertades reproductivas y en un encuadre inequívocamente optimista acerca del desarrollo previsible de las biotecnologías reproductivas, bajo un criterio de precaución muy matizado.

Sin embargo, en Humanity's End (2010) argumenta contra las cuatro líneas de mejora principales (tecnológica, terapéutica, filosófica, sociológica) y su base tecnológica (genética, nanotecnología, robótica). Por tratarse de un autor que ha tenido contribuciones significativas entre 1998 y 2010, coincidiendo con el período de mayor visibilidad académica y mediática del debate sobre las tecnologías de mejora humana, considero que merece la pena indagar las razones de esta evolución.

Los trabajos de Agar resultaron provocativos en muchos aspectos, si se tiene en cuenta las reacciones y comentarios críticos de los que fue objeto. De modo muy directo, contribuyó al interés sobre los aspectos éticos, sociales y legales de múltiples aplicaciones tecnológicas -no sólo las reproductivas- con fines de mejora en las principales revistas de bioética: Bioethics, The Hastings Center Report, The American Journal of Bioethics, The Journal of Medicine and Philosophy, entre otras. En los años 2013 y 2014 han destacado algunas más que amplían temas previos o introducen elementos novedosos, como The Journal of Medical Ethics, Neuroethics, The Journal of Medical Humanities, Journal of Ethics, Science and Engineering Ethics y Medicine, Health Care and Philosophy, entre otras. En todas ellas, las referencias a los trabajos de Agar constituyen un elemento ineludible en los antecedentes.

\section{Obras de referencia}

Las contribuciones de N. Agar han seguido la evolución de los desarrollos biotecnológicos con mayor impacto en el debate social. En particular, las innovaciones en tecnologías reproductivas (Perfect Copy. Unravelling the Cloning Debate, 2002; Life's Intrinsic Value. Science, Ethics, and Nature, 2001) y las implicaciones de su convergencia con los desarrollos en otros dominios científico-tecnológicos ("Whereto Transhumanism? The Literature Reaches a Critical Mass", 2007).

1 El núcleo de su posición ya había sido esbozado en Agar, 1998. 
Su posición teóricamente mejor articulada puede constatarse en Liberal Eugenics. In Defence of Human Enhancement (2004). Pero los planteamientos ahí reflejados evolucionaron pronto en aspectos relevantes, lo que hace imprescindible la lectura de Humanity's End. Why We Should Reject Radical Enhancement (2010).

N. Agar comparte con autores como Ray Kurzweil, James J. Hughes y Lee M. Silver, entre otros muchos, el entusiasmo ante aplicaciones no estrictamente terapéuticas de las biotecnologías. Coinciden en asumir un optimismo pragmático ${ }^{2}$ como encuadre preferente de las expectativas que el desarrollo acelerado ha ido ampliando en diversos dominios científico-tecnológicos. El enfoque optimista se mantiene incluso aunque muchas de las aplicaciones interesantes no hayan sido validadas para un uso fiable y seguro, conforme a los mejores estándares, en seres humanos.

A favor del encuadre optimista estarían los múltiples desarrollos producidos en los dos últimas décadas en las tecnologías reproductivas, en nanotecnología y en robótica, sin apenas incidentes destacados que hayan contribuido a polarizar el debate social (la excepción, quizá, serían algunos casos sofisticados de dopaje y los fracasos más sonados en los primeros intentos de terapia génica). ${ }^{3}$

En cuanto a los matices asociados al enfoque optimista, la posición de Agar se aproxima más bien al análisis que hace Nick Bostrom de las tecnologías para retrasar el envejecimiento y al que propone Julian Savulescu a propósito de la biomejora funcional y cognitiva, incluyendo en esta última intervenciones destinadas a mejorar las capacidades morales.

N. Agar mantiene posiciones bien diferenciadas de otros autores que a menudo son caracterizados como bioconservadores (J. Habermas, F. Fukuyama, B. McKibben, L. Kass, M. Sandel), pero aporta elementos propios en el recurso al principio de precaución que lo distancian de Bostrom y Savulescu. ${ }^{4}$ Presente en el debate especializado durante más de una década, Agar aporta una perspectiva interesante y planteamientos más consistentes de lo habitual en un dominio de problemas que hoy resulta bastante complejo.

\section{Contra el lobby bioconservador estadounidense}

Nicholas Agar no es un entusiasta de las biotecnologías de mejora, pese a lo que algunos apartados de Liberal Eugenics pueden sugerir. Se muestra cauteloso ante la falta de desarrollo y validación de muchas tecnologías para su uso en humanos (en relación con la clonación, p.ej. $)^{5}$. Pero es muy consciente de la influencia política que tiene el lobby bioconservador en EEUU, con capacidad demostrada para condicionar el debate social y prohibir determinadas aplicaciones o limitar el desarrollo de áreas estratégicas de investigación biomédica y retrasar aplicaciones prometedoras. ${ }^{6}$

2 Cfr. Liberal Eugenics, 2004, p. 20.

3 Cfr. CAS 201 1/A/2384 UCI v. Alberto Contador Velasco \& RFEC - Page 2; CAS 2011/A/2386 WADA v. Alberto Contador Velasco \& RFEC; Wilson, J. M. (2009), «A History Lesson for Stem Cells», Science, 324 (5928), pp. 727-728; Gore, M.E. (2003), «Adverse effects of gene therapy: Gene therapy can cause leukaemia: no shock, mild horror but a probe», Gene Therapy, 10 (1), p. 4.

4 Cfr. Agar, 2004, pp. 158-159.

5 Cfr. Agar, 2004, pp. 7-11; 22-25; 33-38; 43-48; 50-52; 133-139; 153.

6 La administración Bush prohibió en 2001 destinar fondos federales a la investigación con nuevas líneas de células troncales obtenidas de embriones humanos, si bien de las 71 líneas previas que cumplían los 
Entre los adversarios naturales de los planteamientos de N. Agar habría que incluir a Leon Kass (conocido por su apelación a la sabiduría de la repugnancia), Francis Fukuyama (para quien la humanidad es demasiado frágil ante el potencial de las tecnologías reprogenéticas) y Bill McKibben (quien desconfía tanto de la mejora como de cualquier tecnología potencialmente destructiva del entorno natural) o Michael Sandel (que cuestiona el derecho de los padres a elegir modificaciones genéticas, por limitadas que sean, en los hijos). ${ }^{7}$ Frente a tales interlocutores, Agar se ubica con más rigor en un dominio ideológico propio y analiza sobre multitud de ejemplos la complejidad de los cambios en la dinámica social inducidos por el desarrollo de la investigación biomédica.

Agar es consciente del sesgo que induce cualquier enfoque centrado en el status quo, en línea con la advertencia al respecto que hacen Nick Bostrom y Toby Ord en "The Reversal Test: Eliminating Status Quo Bias in Applied Ethics" (Ethics 116, 2006, pp. 656-679). Este sesgo implica asumir que el estado actual de cosas es mejor que sus alternativas. Su empleo habitual en los debates tiene como objetivo limitar el desarrollo de enfoques innovadores y retrasar la aplicación de soluciones más sofisticadas a problemas actuales. Pero esta posición típica de autores bioconservadores es instrumentalizada por Agar para sugerir que la mayoría objetan sólo por intentar defender valores cuya radicalización es previsible únicamente en individuos mejorados, con vidas más longevas e intelectos mucho más desarrollados:

Against the conservatives, I argue that enhancement is not incompatible with a meaningful human life. But against the transhumanists, I offer no unconditional endorsement of the idea that we should use technological means to increase the psychological and physical vigour of our descendents.

[...] Furthermore, the onus will be on those with very ambitious visions of enhancement to show that they do not harm those they bring into existence. ${ }^{8}$

\section{Un análisis que integra las dimensiones política y científico-tecnológica}

Para Agar existe una diferencia esencial entre la eugenesia liberal contemporánea y los programas eugenésicos totalitarios centrados en concepciones monistas de la excelencia

requisitos para seguir obteniendo financiación sólo 21 mostraron alguna utilidad. Esta circunstancia obligó a los responsables de proyectos de investigación a idear fórmulas extraordinariamente imaginativas -y poco eficientes, en su mayoría- de colaboración público-privada. Cfr. Murugan, V. (2009), "Embryonic Stem Cell Research: A Decade of Debate from Bush to Obama." Yale J Biol Med., 82 (3), pp. 101-103; Wert, D.C. (2002), "Embryo and stem cell research in the United States: history and politics", Gene Therapy 9, pp. 674-678. Las restricciones se mantuvieron hasta que la FDA cambió sus directrices, con la llegada del presidente Obama. Cfr. BBC, 23/01/2009, http://news.bbc.co.uk/2/hi/health/7847450.stm.

7 Cfr. Kass, L. (1997), "The wisdom of repugnance: Why we should ban the cloning of humans", en The New Republic, 2 June 1997, pp. 17-26; Kass, L., Life, Liberty and the Defense of Dignity: The Challenge for Bioethics. San Francisco, CA, Encounter Books, 2002; Kass, L., Human Cloning and Human Dignity: The Report of the President's Council on Bioethics, New York, Public Affairs, 2002. De F. Fukuyama véase, p.ej., Our Posthuman Future: Consequences of the Biotechnology Revolution, New York, Farrar, Straus \& Giroux, 2002. De B. McKibben, véase Enough: Staying Human in an Engineered Age, New York, Times Books, 2003; y de Michael Sandel, véase The Case against Perfection: Ethics in the Age of Genetic Engineering, Cambridge, Mass., Harvard University Press, 2009.

8 Cfr. Agar, 2004, p. 19. 
humana. Otorga una importancia crucial al desarrollo tecnológico producido entre los programas eugenésicos de comienzos del siglo XX y el escenario tecnológico consolidado en la primera década del siglo XXI. Esta transición ha dejado en segundo plano el optimismo inicial acerca del potencial que tendría la manipulación de factores hereditarios individuales y ha favorecido una evaluación más rigurosa de las biotecnologías de mejora actuales, sobre un trasfondo que ya no es única ni preferentemente el de las biotecnologías reproductivas.

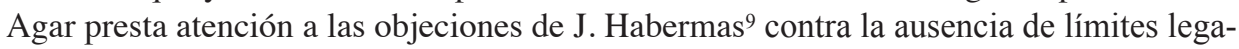
les -en una sociedad liberal-y su efecto determinante en la elección de rasgos deseables a promover en la descendencia, bajo criterio exclusivo de los padres. Pero asume que el ejercicio de las libertades en las sociedades liberales siempre está limitado, aunque la cuestión de cómo hacerlo requiera reflexiones adicionales (algunas pueden explorarse a través de la selección de lecturas que propone). ${ }^{10}$

No es frecuente encontrar en otros autores que se ocupan de la problemática una contextualización del desarrollo tecnológico como la que Agar lleva a cabo. En las primeras páginas de Liberal Eugenics alude a las que considera más prometedoras en ese período:

A collection of technologies that I will call enhancement technologies will enable the selection and manipulation of human traits by selecting and manipulating the hereditary factors that contribute to them. [...] The most topical of these technologies is cloning. (LE, p. 7)

Another biotechnology might enable more precise choices of hereditary influences. This is the biotechnology of genomics, whose task is to describe hereditary material. [...] The human genome had been described to 99.99 per cent accuracy. The job of identifying all the human genes and determining their functions remains. (LE, p. 10). PGD allows parents-to-be to choose from the variation provided by nature. Genetic engineers allow them to improve on nature. They would insert genes linked with traits valued by parents into the genomes of their future children. (ibid.)

Y no duda en aportar referencias para darle un encuadre irónico a las expectativas exageradas que sobre algunas de ellas se proyectan. ${ }^{11}$

\section{Importancia del análisis prospectivo riguroso en el debate ético}

Agar considera importante contribuir de modo riguroso a anticipar escenarios que pueden adelantarse mucho más de lo esperado, como ha ocurrido en numerosas ocasiones en la $\mathrm{I}+\mathrm{D}$ de la segunda mitad del siglo XX. Discrepa de quienes sugieren posponer el debate sobre opciones morales que resultarían ineludibles en escenarios tecnológicos aún distantes.

Para Onora O’Neill, p.ej., el estado actual de las tecnologías de mejora no pasa de incipiente, lo que reduce la urgencia del debate moral sobre sus aplicaciones. Su propuesta invita a centrarnos en evaluar tecnologías reproductivas que ya están aquí (O’Neill, 2002).

9 Cfr. Habermas, J., The Future of Human Nature, Cambridge, Polity Press, 2003.

10 Cfr. "Further Reading", en Agar, 2004, pp. 188-191.

11 Es el caso cuando cita a Carl Elliott, Better than Well: American Medicine Meets the American Dream, New York, W. W. Norton, 2003. 
Pero Agar es consciente de que la mejora humana no sólo será posible en un futuro lejano, puesto que el diagnóstico genético prenatal (PGD) o la clonación reproductiva permiten ya elegir algunas características de los hijos.

En este aspecto, el criterio de Agar y su análisis del potencial asociado con ciertas líneas de investigación resultan más rigurosos. Es obvio que el desarrollo científico ha proporcionado múltiples sorpresas con notable impacto en el debate moral. En la década de 1930 no se consideraba verosímil que la energía atómica pudiera ser utilizada con fines destructivos, algo que estaba muy próximo. Y en la década de los ochenta los biólogos Davor Solter y James McGrath, tras realizar una serie exhaustiva de experimentos con manipulación de núcleos de células de ratón diferenciadas en óvulos fertilizados, concluyeron erróneamente que "la clonación de mamíferos, mediante una simple transferencia nuclear [de células somáticas], es biológicamente imposible". ${ }^{12}$

El análisis contextualizado de Agar destaca frente al de otros autores que no consideran necesario esbozar un escenario viable muy detallado para proyectar el debate social. Es el caso de Nick Bostrom y su análisis del impacto social de las tecnologías para retrasar el envejecimiento, explorando el alcance de eventuales aplicaciones muy alejadas del potencial científico-tecnológico actual. Bostrom (2003, pp. 493-506) resta importancia a los detalles que explican la capacidad para configurar la opinión pública de relatos distópicos sobre las biotecnologías como Gattaca (de Andrew Niccol, estrenada en 1997) y otras obras de ficción, la cuales coinciden en señalar el riesgo de un acceso muy desigual a las aplicaciones avanzadas más costosas que terminaría favoreciendo los intereses de una élite genética insensible al bienestar de los no mejorados.

Agar toma muy en serio la objeción distópica, explorando riesgos de cuya gestión no se tienen precedentes satisfactorios y para los cuales el encuadre distópico no resulta una alternativa descabellada. De hecho, en Humanity's End admite que las tecnologías de mejora radical tienen el poder de crear seres cuyas dotes intelectuales y físicas podrían estar mucho más desarrolladas que las de las individuos considerados válidos en Gattaca (Agar, 2010, p. 10), por lo que desconfía de la noción de transhumanismo democrático que propone James Hughes y de su utilidad para un futuro social armonioso (Agar, 2010, pp. 152-157; Hughes, 2004).

Agar considera preferible aplicar las categorías de conquistador y colonizador, tan frecuentes en los relatos de ciencia ficción que exploran las posibilidades de la inteligencia artificial, de la robótica y de la biónica. Y nada ajenas a los múltiples elementos considerados por Bostrom en su exhaustivo análisis de las amenazas previsibles asociadas al desarrollo de la inteligencia artificial avanzada, al que se sumaron pronto otros muchos expertos (Bostrom 2014; Bostrom 2002; Bostrom and Yudkowsky 2013; Marcus 2013; Bianchini 2016).

\section{Sesgos del optimismo pragmático en el debate social}

El compromiso de Agar con cierto optimismo pragmático no opera debilitando la calidad y el rigor de su análisis prospectivo, como ocurre en planteamientos de otros autores más entusiastas de la retórica transhumanista:

12 Cfr. McGrath, J. and Solter, D., Science 226, 1984, pp. 1317-1319. 
We can imagine beings that reach a much greater level of personal development and maturity than current human beings do, because they have the opportunity to live for hundreds or thousands of years with full bodily and psychic vigor. We can conceive of intellects that are much smarter than our own, that read books in seconds, that are much more brilliant philosophers than we are, that can create artworks, which, even if we could understand them only on the most superficial level, would strike us as wonderful masterpieces. We can imagine love that is stronger, purer, and more secure than any human has yet harbored..$^{13}$

La contención de Agar en su valoración de las tecnologías de mejora (no las considera idóneas para originar individuos "radicalmente distintos de los humanos", y cuestiona que la mejora radical sea compatible con mantener lo básico para seguir llamándoles humanos) favorece una mayor atención a las implicaciones del mejoramiento moderado, con el cual asocia problemas éticos de calado. ${ }^{14}$

Agar no trivializa el sentido de "posthuman". En este aspecto su posición se acerca más a la de incompatibilistas como Nick Bostrom y James Hughes, quienes enfatizan las diferencias entre los individuos radicalmente mejorados y los humanos con el rango características físicas y cognitivas que conocemos hoy.

El planteamiento de Agar contrasta sobre todo con el de Ray Kurzweil, quien sostiene que seguiríamos siendo reconociblemente humanos incluso después de haber sido "volcados" en un superordenador (Agar, 2010, pp. 18 y 56-81; Kurzweil, 2005, caps. 5, 8 y 9). La atención a los detalles en el ejercicio de prospectiva es particularmente sutil en las secciones Searle's Wager y Why We Shouldn't Make Electronic Copies of Ourselves (Agar, 2010, pp. 63-67; 73-77).

Los matices de Agar a propósito del programa de inteligencia artificial en curso refuerzan la importancia de explorar en qué aspectos las tecnologías de la computación acelerarán el rendimiento humano y si los desarrollos en el diseño de sistemas computacionales avanzados potenciarán el programa fuerte de inteligencia artificial hasta un umbral en el que sus logros no puedan distinguirse de los de seres humanos.

A pesar del olfato demostrado por R. Kurzweil para intuir las transformaciones tecnológicas resultantes de combinar desarrollos en dominios tecnológicos muy diversos y anticipar aplicaciones con potencial para modificar de modo irreversible la vida humana, unos años de perspectiva entre las obras de Kurzweil (1992, 1999, 2005), las de Agar (2004, 2010) y la obra reciente de referencia sobre el asunto (Superintelligence, de N. Bostrom, publicada en 2014) ${ }^{15}$ permiten apreciar que el planteamiento de Agar sobre la problemática resulta más compatible que el de Kurzweil con la percepción actual de riesgos asociados al programa de inteligencia artificial fuerte y con la sucesión de logros en los intentos de emular funciones complejas del cerebro humano. El diseño de máquinas capaces de sustentar procesos conscientes complejos continúa siendo un desafío tecnológico descomunal (Frankish and Ramsey 2014, cap. 12; Chalmers, 2010; Nof, 2009, pp. 311-312).

13 Cfr. Bostrom, 2003, pp. 494-495.

14 "Moderate enhancement raises serious moral issues" (Agar, 2010, pp. 17).

15 Traducida ya al español: Bostrom, N. (2016). Superinteligencia: caminos, peligros, estrategias. Zaragoza: TEELL. 
Agar se distancia también del costoso programa que propone Aubrey de Grey para acabar con el envejecimiento, "el peor problema de la humanidad" (de Grey, 2007). De Grey pretende no sólo retrasar, sino acabar con el envejecimiento en la especie humana mediante una combinación de estrategias (habla de reescribir las reglas del juego la vida) que reducirían la senescencia a algo insignificante. Según Agar, no es previsible que de Grey tenga éxito a medio plazo, dada la complejidad de los factores involucrados (genéticos, ambientales) y la falta de conocimiento básico en biología relacionado con las interacciones epigenéticas, entre otros obstáculos.

\section{Obstáculos para una teoría liberal comprometida con un programa de mejora}

Merece la pena considerar la sutileza del análisis de Agar frente a la especulación sociopolítica bienintencionada de James Hughes. Asumido el riesgo de un conflicto de intereses entre seres humanos mejorados y normales -los individuos mejorados pueden considerar a los normales un obstáculo para sus aspiraciones legítimas de mejora-, Hughes sugiere que no quedará otra alternativa que redefinir nociones políticas básicas como la de ciudadanía, para inducir los ajustes necesarios en los pactos sociales que garantizan derechos y libertades (Hughes, 2004, pp. 221-240).

Hughes propone articular una noción de democracia transhumanista acorde a la mejora moral requerida para evitar la colisión de proyectos de vida alternativos (Hughes, 2004, pp. 187-220). Enfatiza la libertad individual, pero atribuye al Estado potestad para corregir las desigualdades en el acceso a este tipo de tecnologías y para disuadir a las personas de hacer malas elecciones. Pero Agar considera que el apoyo directo a la mejora radical colisiona con el pretendido enfoque liberal:

Classical liberals do not present themselves as marketing any particular view of human excellence. Rather, they defend institutions that allow individuals to make their own choices about how to live. Liberal pluralism about the good life carries over to decisions about what to view as an enhancement. The many different views about which is the best life lead to equally many views about what modifications to children's DNA actually enhance them. Liberals ask only that our choices be consistent with our children's well-being. ${ }^{16}$

En este aspecto Agar coincide con varias tesis de D. Fox, para quien los casos de eugenesia liberal obligatoria constituyen una reducción al absurdo de la teoría liberal (Fox, 2007:1-5). Pero constituye un buen ejemplo para justificar un análisis más pormenorizado que el propuesto por Hughes. La función del Estado no se limita a eliminar los obstáculos para que los ciudadanos ejerzan su capacidad de autonomía. Los estados liberales obligan a prácticas que mejoran en general los recursos considerados de propósito general para la vida de los niños, en un sentido equivalente a lo que Rawls llama bienes sociales primarios (social primary goods). Los bienes naturales primarios consisten en capacidades mentales y físicas hereditarias valoradas positivamente para un amplio rango de planes de vida diversos y viables (Rawls, 1997).

16 Cfr. Agar, 2010, p. 190. 
Según Fox, los bienes primarios incluyen ausencia de discapacidad, resistencia a las enfermedades, movilidad física y coordinación, percepción visual y auditiva, memoria a corto y largo plazo, razonamiento verbal y espacial, capacidad cognitiva general y ciertas conductas características (reflexividad, control de impulsos, búsqueda de novedad, capacidad de adaptarse a la adversidad...). Valdrían para cualquier proyecto vital. Los bienes naturales primarios incorporan un elemento perfeccionista, ya que favorecen vidas compatibles con un rango significativamente amplio de proyectos vitales. El Estado puede fomentar la autonomía en estos aspectos sin menoscabar el pluralismo sobre un marco de neutralidad minimalista. Privar de alguno de estos bienes naturales no hace la autonomía imposible, pero reduce significativamente las opciones vitales de los individuos.

Los bienes naturales primarios pueden distinguirse de los bienes naturales no primarios (rasgos influidos genéticamente que pueden ser ventajosos para algún proyecto vital que el descendiente pueda escoger, pero no para otros: sexo y altura, sociabilidad y timbre de voz, lealtad y generosidad, color de la piel, orientación sexual, etc. serían bienes no primarios). La compatibilidad entre las propuestas de Hughes y las cautelas de Agar pasa por incorporar un enfoque más amplio como el que aporta D. Fox, quien presupone el consentimiento informado hipotético a las vidas prenatales para la mejora de bienes naturales primarios como base de una teoría alternativa a la eugenesia liberal que se sustenta en un desarrollo no problemático del estatus moral de las prácticas de crianza dentro del marco liberal (Fox la denomina teoría liberal de la mejora de la descendencia).

\section{Conclusión}

El debate sobre el empleo de tecnologías de mejora en seres humanos ha evolucionado desde una fase donde predominaba el análisis prospectivo de carácter especulativo sobre posibles transformaciones biotecnológicas (mediante técnicas de clonación, ingeniería genética y selección de embriones) a otra en la que la introducción de mejoras funcionales y cognitivas radicales en humanos parece depender sobre todo del potencial de las nanotecnologías, la robótica y la inteligencia artificial.

En Humanity's End (2010), N. Agar argumenta contra las cuatro líneas de mejora principales (tecnológica, terapéutica, filosófica, sociológica) y su base tecnológica: genética, nanotecnología, robótica y computación. Una perspectiva ampliada de la reflexión iniciada en Liberal Eugenics (2004) obliga a descartar toda valoración que lo aproxime a entusiastas de las biotecnologías de mejora como A. Sandberg (2011), de Grey (2007), Hughes (2004) o Bostrom (2003). A diferencia de estos, Agar muestra mayor cautela ante la falta de desarrollo y validación de muchas tecnologías para su uso en humanos, aunque es consciente de la necesidad de contrarrestar la influencia del colectivo bioconservador estadounidense en el marco legal que regula la investigación biomédica.

N. Agar analiza con rigor las posibilidades tecnológicas abiertas para los programas de eugenesia liberal contemporáneos. Pero su estudio aporta una contextualización más amplia -enriquecida con ejemplos extraídos de dominios tecnológicos diversos y de la historia de la tecnología en el siglo XX- que las derivadas de planteamientos inequívocamente optimistas como los de J. Hughes o R. Kurzweil. Este aspecto influye en una valoración de riesgos mejor articulada y compatible con los escenarios tecnológicos y reguladores que hoy resultan verosímiles. 
En conjunto, las aportaciones de N. Agar entre 2004 y 2010 constituyen un ejercicio riguroso de prospectiva científico-tecnológica. Su análisis resulta particularmente útil para abordar tanto las tecnologías de mejora funcional y cognitiva en humanos como el potencial de otras tecnologías -inteligencia artificial, robótica, biónica- susceptibles de ser empleadas con objetivos similares, y con igual o mayor versatilidad para contribuir a una distribución desigual de oportunidades.

\section{Referencias}

Agar, N. (1998): Liberal Eugenics, Public Affairs Quarterly 12 (2), pp. 137-155. Disponible en: http://writingbio.qwriting.qc.cuny.edu/files/2011/08/agar.pdf.

Agar, N. (2001): Life's Intrinsic Value. Science, Ethics, and Nature, Columbia University Press, New York.

Agar, N. (2002): Perfect Copy. Unravelling the Cloning Debate. Icon Books - Cox \& Wyman Limited, Reading.

Agar, N. (2004): Liberal Eugenics. In Defence of Human Enhancement, Oxford, Blackwell Publishing Ltd.

Agar, N. (2007): Whereto Transhumanism? The Literature Reaches a Critical Mass, Hastings Center Report 37 (3), pp. 12-17.

Agar, N. (2010): Humanity's End. Why We Should Reject Radical Enhancement, Cambridge, Massachusetts / London, A Bradford Book - The MIT Press.

Bianchini, F. (2016): Artificial Intelligence and Synthetic Biology: A Tri-Temporal Contribution. Biosystems, January. doi:10.1016/j.biosystems.2016.01.001.

Bostrom, N. (2002): Existential Risks: Analyzing Human Extinction Scenarios and Related Hazards. Journal of Evolution and Technology 9, March, pp, 1-30. Disponible en http:// www.jetpress.org/volume9/risks.html.

Bostrom, N. (2003): Human Genetic Enhancements: A Transhumanist Perspective, Journal of Value Inquiry, 37 (4), pp. 493-506.

Bostrom, N. (2014): Superintelligence: Paths, Dangers, Strategies. Oxford, Oxford University Press. (vers. esp.: Bostrom, N. (2016). Superinteligencia: caminos, peligros, estrategias. Traducción de Marcos Alonso. Zaragoza: Teell Editorial).

Bostrom, N., Yudkowsky, E. (2014): The Ethics of Artificial Intelligence. En Frankish, K., \& Ramsey, W. M., The Cambridge Handbook of Artificial Intelligence, Cambridge University Press, cap. 15.

Brighouse, H., Robeyns, I. (2010): Measuring justice: primary goods and capabilities, Cambridge England New York, Cambridge University Press.

Chalmers, D. J. (2010): The Singularity: A Philosophical Analysis, Journal of Consciousness Studies 17 (9-10), 7-65.

De Grey, A. (2007): Ending Aging: The Rejuvenation Breakthroughs That Could Reverse Human Aging in Our Lifetime, New York, St Martin's Press.

Fox, D. (2007): The illiberality of 'liberal eugenics', Ratio, Vol. 20(1), pp. 1-25.

Frankish, K. y Ramsey, W. M. (2014), The Cambridge Handbook of Artificial Intelligence. Cambridge University Press, 2014.

Habermas, J. (2003): The Future of Human Nature, Cambridge, Polity Press. 
Hughes, J. (2004): Citizen Cyborg: Why Democratic Societies Must Respond to the Redesigned Human of the Future, Cambridge, Mass., Westview.

Kurzweil, R. (1992): The Age of Intelligent Machines, MIT Press, Cambridge.

Kurzweil, R. (1999): The Age of Spiritual Machines: When Computers Exceed Human Intelligence, Viking, New York.

Kurzweil, R. (2005): The Singularity Is Near: When Humans Transcend Biology, London, Penguin.

Marcus, G. (2013): Why We Should Think About the Threat of Artificial Intelligence. Disponible en: http://www.newyorker.com/tech/elements/why-we-should-think-aboutthe-threat-of-artificial-intelligence.

Nof, S. Y. (ed.): Springer Handbook of Automation, Heidelberg, Springer Berlin Heidelberg, 2009. doi:10.1007/978-3-540-78831-7.

O’Neill, O. (2002): Autonomy and Trust in Bioethics, Cambridge, Cambridge University Press.

Rawls, J. (1997): Social unity and primary goods, Frontier Issues in Economic Thought 3, pp. 276-280.

Sandberg, A. (2011): Cognition Enhancement: Upgrading the Brain, en J. Savulescu, R. ter Meulen, \& G. Kahane (Eds.), Enhancing human capacities, Chichester, West Sussex, U.K. Malden, MA, Wiley-Blackwell.

Sandel, M. (2009): The Case against Perfection: Ethics in the Age of Genetic Engineering, Cambridge, Mass., Harvard University Press.

Silver, Lee M. (1998): Vuelta al Edén. Más allá de la clonación en un mundo feliz, Taurus, Madrid. 
